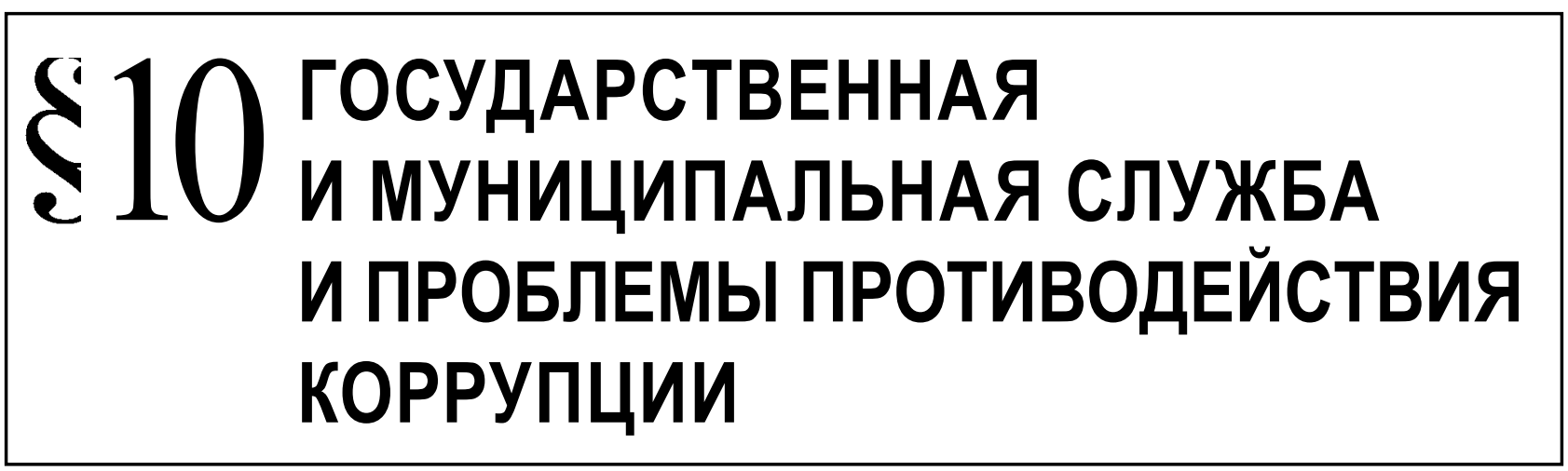

Кабанов П.А.

\title{
О СООТНОШЕНИИ АНТИКОРРУПЦИОННОГО ОБРАЗОВАНИЯ И АНТИКОРРУПЦИОННОГО ПРОСВЕЩЕНИЯ КАК ВИДОВ АНТИКОРРУПЦИОННОЙ ДЕЯТЕЛЬНОСТИ
}

Аннотация. Предметом проведенного исследования является выяснение сущностных характеристика антикоррупционного просвещения и антикоррупционного образования как двух взаимсвязанных и взаимозависимых видов антикоррупционной деятельности и их соотношение между собой. Задачами исследования являются: а) раскрытие сущностных характеристик антикоррупционного просвещения и антикоррупционного образования; б) дать соотношение антикоррупционного просвещения и антикоррупционного образования как видов антикоррупционной деятельности; в) найти общее и особенное в антикоррупционном образовании и антикоррупционном просвещении; г) проанализировать нормативные правовые акты регулирующие вопросы антикоррупционного просвещения и антикоррупционного образования. Методологической основой выступил диалектический материализм, а в качестве основного метода - структурный анализ, позволивший определить соотношение антикоррупционного просвещения и антикоррупционного образования. Основными выводами проведенного исследования являются: а) антикоррупционное образование и антикоррупционное просвещение - это разные средства противодействия коррупции, обладающие значительным антикоррупционным потенциалом, хотя и имеющие определенные сходства между собой; б) они отличаются друг от друга по всем структурным элементам: целям и задачам, субъектам и объектам, средствам осуществления, правовому регулированию и правовым последствиям.

Ключевые слова: коррупция, противодействие коррупции, антикоррупционная политика, антикоррупционное образование, антикоррупционное просвещение, профилактика коррупции, антикоррупционное информирование, антикоррупционное мировоззрение, антикоррупционное поведение, антикоррупционная деятельHocmb.

Review. The research focuses on the essential characteristics of anti-corruption enlightenment and anti-corruption education as two interconnected and interdependent forms of anti-corruption activity, and their correlation. The study aims at: a) revelation of essential characteristics of anti-corruption enlightenment and anti-corruption education; b) assessment of their correlation as the forms of anti-corruption activity; c) outlining of the common and the specific features of both notions; d) the analysis of normative legal acts regulating the sphere of anti-corruption enlightenment and education. The methodology is based on dialectical materialism; the main research method is structural analysis which helped to define the correlation of anti-corruption enlightenment and education. The main conclusions of the study are: a) anti-corruption education and anti-corruption enlightenment are different means of combating corruption with a significant anti-corruption potential, though having some similarities; b) they differ in all structural elements: goals and tasks, subjects and objects, means of implementation, legal regulation and legal consequences.

Keywords: anti-corruption informing, prevention of corruption, anti-corruption enlightenment, anti-corruption education, anti-corruption policy, combating corruption, Corruption, anti-corruption worldview, anti-corruption behavior, anticorruption activity. 
$\prod$ ротиводействие коррупции как целенаправленная деятельность органов государственной власти и институтов гражданского общества по снижению коррупциогенности отношений между чиновниками и населением - длительный и не прекращающийся процесс в большинстве государств мира. Для снижения коррупциогенности общественных отношений выработаны и эффективно применяются различные инструменты противодействия коррупции, которые с различной степени результативности воздействуют на коррупцию и порождающие её причины. Среди таких инструментов современное российское федеральное и региональное антикоррупционное законодательство выделяет: антикоррупционную экспертизу нормативных правовых актов и проектов нормативных правовых актов; антикоррупционный мониторинг; антикоррупционное планирование; антикоррупционную пропаганду; антикоррупционное образование и антикоррупционное просвещение. В той или иной степени содержанию этих видов антикоррупционной профилактики дается свое легальное правовое определение и раскрывается его содержание. Однако, такие правовые дефиниции довольно часто противоречат друг другу, запутывая правоприменительную деятельность. Одновременно отечественными и зарубежными специалистами предлагаются меры по совершенствованию названных дефиниций и повышению эффективности названных видов антикоррупционной деятельности. Создаются специальные терминологические словари для унифицированных подходов к определению различных видов противодействия коррупции $[1 ; 2 ; 3 ; 6 ; 7 ; 9]$, но и они не позволяют в значительной мере даже специалистам отличить один вид антикоррупционной деятельности от другого. Наиболее часто в федеральных и региональных нормативных правовых актах при описании профилактических мер происходит путаница между такими видами противодействия коррупции как антикоррупционное просвещение, антикоррупционное образование, антикоррупционная пропаганда и антикоррупционное информирование. Среди названных антикоррупционных средств профилактического воздействия наиболее часто отождествляются такие виды деятельности как антикоррупционное образование и антикоррупционное просвещение и не только в региональной правотворческой деятельности [43], но и при проведении исследований по вопросам противодействия коррупции [35; 37]. Хотя вопросам организации и осуществления антикоррупционного образования $[4$, с.16-18; 5 , с.4-9; 8, с.13-15; 11, с.174-179; 12, с.15-18; 14, с.156$160 ; 15$, c.36-40; 20, c.12-18; 22, c.180-181; 23, c.185$189 ; 24$, c.7-9; 25, с.268; 26, с.138-146; 27, c.286-292; 28 , с.97-101; 29, с.601-612; 32, с.20-25; 33, с.76-80; 34, c.150-154] и антикоррупционного просвещения [10, с.11-15; 13, с.47-53; 17, с.42-51; 18, с.27-29; 19, c.12-27; 23, с.8-13; 30, с.188-191; 31, с.106-109; 36, c.5] посвящено значительное количество научных исследований, результаты которых уже опубликованы в российских научных изданиях. Названные проблемы, посвященные разграничению понятий и видов антикоррупционной деятельности, делают подобного рода исследования для различных групп исследователей - актуальными, а для специалистов в области реализации государственной политики противодействия коррупции - востребованными в повседневной деятельности.

Эмпирической основой проведенного исследования выступили 218 федеральных и региональных нормативных правовых актов по вопросам противодействия коррупции, в которых отражены антикоррупционное образование и антикоррупционное просвещение как средства противодействия коррупции, предыдущие исследования автора по названной проблематике, а также результаты исследований других специалистов, проведенных ранее.

Для достижения основной цели исследования - выявить общее и особенное между антикоррупционным образованием и антикоррупционным просвещением мы решили использовать метод структурного анализа, который на наш взгляд, может привести к достижению названной цели. В качестве общих основных структурных элементов антикоррупционного образования и антикоррупционного просвещения как инструментов противодействия коррупции, которые необходимо исследовать мы выделили: а) цели и задачи; б) субъекты; в) объекты; г) средства; д) правовое регулирование; е) правовые последствия.

Обратившись к одной из основных структурных единиц названных видов антикоррупционной деятельности - целям, мы обнаруживаем следующее: целями антикоррупционного просвещения является информирование населения (неопределенного круга лиц) по вопросам противодействия коррупции, а основной целью антикоррупционного образования выступает формирование антикоррупционной компетентности обучающихся (определенного круга лиц). Очевидно, что конечные цели антикоррупционного образования и антикор- 
рупционного просвещения как самостоятельных инструментов противодействия коррупции, не совпадают. Возможно, у них могут совпадать промежуточные цели, чаще именуемые задачами.

Как показывает практика правового регулирования вопросов противодействия коррупции, основными задачами антикоррупционного просвещения являются формирование антикоррупционного мировоззрения, антикоррупционного поведения, антикоррупционного сознания и антикоррупционной культуры, а основными задачами антикоррупционного образования является повышение уровня уже сформировавшегося антикоррупционного правосознания и антикоррупционной культуры. Здесь очевидна общность некоторых задач, стоящих перед названными инструментами государственной политики противодействия коррупции. Однако задачи антикоррупционного образования отличаются достижением более высокого уровня антикоррупционного мировоззрения, антикоррупционного поведения, антикоррупционного сознания и антикоррупционной культуры, тогда как при антикоррупционном просвещении задачи сводятся к начальной стадии процесса - формированию антикоррупционного мировоззрения, антикоррупционного поведения, антикоррупционного сознания и антикоррупционной культуры.

Несколько по-особенному выглядят объекты исследуемых видов антикоррупционной деятельности. Объектом информационного воздействия при осуществлении антикоррупционного просвещения выступает население, то есть неопределенный круг лиц, а при осуществлении антикоррупционного образования - обучающиеся образовательного учреждения или определенная категория населения, получающая антикоррупционные знания, навыки и умения. Хотя наличие неопределенного круга лиц при осуществлении антикоррупционного просвещения не исключает использование этого инструмента в отношении отдельных целевых групп (государственных и муниципальных служащих, руководителей хозяйствующих субъектов, лиц, обязанных предоставлять сведения о доходах и расходах, учащихся образовательных учреждений и т.д.). Следовательно, объект информационного воздействия антикоррупционного просвещения значительно шире, чем объект антикоррупционного образования.

Имеют свою специфику и субъекты, осуществляющие антикоррупционное образование и антикоррупционное просвещение. Субъектами антикоррупционного просвещения выступают широкий круг субъектов, реализующих антикоррупционную политику государства либо прямо предусмотренные региональными нормативными правовыми актами, а антикоррупционного образования - образовательные учреждения, педагогические работники, обладающие соответствующими квалификационными требованиями [16, с.81-92]. Необходимо отметить, что региональными нормативными правовыми актами предусмотрено осуществление антикоррупционного просвещения различными категориями субъектов. Например, в Костромской области в качестве организатора антикоррупционного просвещения выступает Департамент региональной безопасности Костромской области [39], в Архангельской области эта функция возложена на региональное министерство образования и науки [45], в Новосибирской области полномочия по организации и координации антикоррупционного просвещения переданы региональному министерству юстиции [40], в Карачаево-Черкесской Республике антикоррупционного просвещения является одной из основных задач республиканского Управления по реализации антикоррупционной политики [47], в Калининградской области организация и проведение мероприятий по антикоррупционному просвещению возложена на Комиссию Правительства Калининградской области по соблюдению требований к служебному поведению государственными гражданскими служащими Калининградской области и урегулированию конфликта интересов [38].

В качестве одного из критериев соотношения антикоррупционного образования и антикоррупционного просвещения является специфика их правового регулирования. Правовое регулирование антикоррупционного образования осуществляется по государственным образовательным стандартам в соответствии с законодательством об образовании и региональным антикоррупционным законодательством, а антикоррупционное просвещение осуществляется в соответствии с подзаконными нормативными правовыми актами [48; 49], либо региональным антикоррупционным законодательством [41; 42; 45]. Здесь имеется общее правовое пространство - эти два вида антикоррупционной деятельности довольно часто регулируются положениями регионального антикоррупционного законодательства.

Обратившись к анализу средств реализации анализируемых инструментов противодействия коррупции обнаруживаем следующее: при осуществлении антикоррупционного образования 
используются исключительно средства образовательного процесса, предусмотренные образовательными стандартами и иными, производными от них, документами (лекции, семинарские и практические занятия, аттестация, обеспечение необходимой учебной, учебно-методической и научной литературой и т.д.), тогда как средства антикоррупционного просвещения могут включать в себя не только образовательные средства (лекции, семинарские и практические занятия, обеспечение необходимой литературой), но и другие инструменты, прямо не запрещенные законодательством, например, антикоррупционное консультирование [44]. Здесь следует отметить наличие общности отдельных средств используемых как при осуществлении антикоррупционного просвещения, так и антикоррупционного образования: лекции, семинарские и практические занятия, обеспечение необходимой научной и учебной литературой.

Антикоррупционное образование и антикоррупционное просвещение отличаются ещё по одному критерию - правовым последствиям для лиц подвергшимся этим инструментам государственной антикоррупционной политики. Лица, испытавшие на себе воздействие антикоррупционного образования, получают соответствующие знания, умения и навыки по осуществлению антикоррупционной деятельности и документы, подтверждающие их профессиональную квалификацию, а лица, в отношении которых осуществлялось антикоррупционное просвещение, получают лишь необходимую информацию, пригодную для использования в конкретных жизненных ситуациях. При этом получение антикоррупционного образования позволяет претендовать лицу, его получившему на трудоустройство в сфере организации и осуществления противодействия коррупции, тогда как наличие антикоррупционной информированности лица, в меньшей степени может повлиять на его трудоустройство в сфере противодействия коррупции.

Изложенное выше позволяет утверждать, что антикоррупционное образование и антикоррупционное просвещение - это разные средства противодействия коррупции, обладающие значительным антикоррупционным потенциалом, хотя и имеющие определенные сходства между собой. Они отличаются друг от друга по всем структурным элементам: целям и задачам, субъектам и объектам, средствам осуществления, правовому регулированию и правовым последствиям.

\section{Библиография:}

1. Агеев В.Н., Бикеев И.И., Кабанов П.А. и др. Все о коррупции и противодействии ей: терминологический словарь / под общ. ред. И.И. Бикеева, П.А. Кабанова: Серия в 3 т. Т.2. - Казань: изд-во «Познание», 2014.

2. Антикоррупционная экспертиза нормативных правовых актов и их проектов: терминологический словарь / автсост. В.Н. Агеев, И.И. Бикеев, П.А. Кабанов и др.; рук. авт. коллектива П.А. Кабанов. - Казань: Изд-во «Познание», 2010.

3. Антикоррупционный словарь. - Бишкек: Министерство экономики Кыргызской Республики, 2013.

4. Ахметова Н.А., Гузенко В.Н. Основы антикоррупционного образования в современном учебном процессе // Известия Волгоградского государственного технического университета. - 2013. - Т.10. - №13. - С.16-18.

5. Бикеев И.И., Кабанов П.А. Антикоррупционное образование как один из инструментов противодействия коррупции: вопросы его формирования и реализации в Республике Татарстан // Следователь. - 2010. - №8. - №С.4-9.

6. Бикеев И.И., Кабанов П.А., Чирков Д.К. и др. Коррупция и антикоррупционная политика: терминологический словарь / под общ. ред. Г.И. Райкова, П.А. Кабанова, Д.К. Чиркова. - 5-е изд., перераб. и доп. - М.: МедиаПресс, 2010.

7. Бикмухаметов А.Э., Газимзянов Р.Р., Кабанов П.А., Райков Г.И. Чирков Д.К. и др. Коррупция и антикоррупционная политика: терминологический словарь / под общ. ред. П.А. Кабанова. - М.: МедиаПресс, 2008.

8. Бикмухаметов А.Э., Юсупов И.М. Дополнительное антикоррупционное образование муниципальных служащих: уровни и основные направления подготовки // Актуальные проблемы экономики и права. - 2010. - №4. - С.13-15.

9. Газимзянов Р.Р., Кабанов П.А., Мулюков Ш.М. Коррупция и борьба с ней: краткий терминологический словарь / Под общ. ред. Р.Ф. Муратова, Н.Х. Сафиуллина. - Казань, 2004.

10. Гармаев Ю.П., Фалилеев В.А. Реализация мер антикоррупционного просвещения органами прокуратуры во взаимодействии с юридическими вузами // Государственная власть и местное самоуправление. - 2015. - №1. - С.11-15.

11. Глухова А.А., Мытарев М.В., Шапошников Е.Л. Аналитический обзор реализации образовательных программ в сфере противодействия коррупции в Нижегородской академии МВД России // Юридическая наука и практика: Вестник Нижегородской академии МВД России. - 2014. - №2 (26). - С.174-179.

12. Емельянова Н.И., Подкатилина М.Л. Антикоррупционное образование в российских учебных заведениях // Юридическое образование и наука. - 2014. - №2. - С.15-18.

13. Землин А.И.О новациях и деформациях антикоррупционного просвещения и воспитания в современной России // Противодействие терроризму. Проблемы XXI века. - COUNTER-TERRORISM. - 2014. - №2. - C.47-53.

14. Идрисова С.Ф. Проблемы реализации концепции непрерывного антикоррупционного образования элиты // Актуальные проблемы экономики и права. - 2010. - №2. - С.156-160. 
15. Кабанов П.А. Антикоррупционное образование в органах внутренних дел Российской Федерации: современное состояние и перспективы развития // Следователь. - 2011. - №2. - С.36-40.

16. Кабанов П.А. Антикоррупционное образование как правовая категория регионального антикоррупционного законодательства: опыт критического анализа // Полицейская деятельность. - 2014. - №1. - C.81-92.

17. Кабанов П.А. Антикоррупционное просвещение как средство противодействия коррупции: понятие и содержание // Актуальные проблемы экономики и права. - 2014. - №4. - С.42-51.

18. Кабанов П.А. О формировании Программы мероприятий, направленных на повышение уровня правосознания граждан и популяризацию антикоррупционных стандартов поведения, основанных на знании общих прав и обязанностей // Следователь. - 2014. - №1. - С.27-29.

19. Кабанов П.А. Понятие и содержание антикоррупционного просвещения как средства профилактики коррупции // Юридические исследования. - 2015. - № 2. - С.12-27.

20. Кодан С.В. Антикоррупционная подготовка государственных служащих и административная реформа // Чиновник. - 2005. - №3(37). - С.12-18.

21. Корякин В.М. Антикоррупция - 2014: приоритет - борьбе с «откатами» и антикоррупционное просвещение военнослужащих // Право в Вооруженных силах. - 2014. - №12 (210). - С.8-13.

22. Кос Д. Опыт европейских стран в сфере создания и функционирования специального органа, ответственного за координацию государственных мер по противодействию и предотвращению коррупции // Россия - Европа. Вместе против коррупции: Материалы совместного проекта «Разработка законодательных и иных мер предупреждения коррупции в Российской Федерации» (RUCOLA-2). - M., 2008. - Часть 2. - C.180-181.

23. Николаев С.М. Введение в проблему специального антикоррупционного образования // Фундаментальные исследования. - 2014. - №9-1. - С.185-189.

24. Николаев С.М. Знания, умения, навыки и компетенции при реализации антикоррупционного образования // Вестник гуманитарного научного образования. - 2013. - №8 (34). - С.7-9.

25. Николаев С.М. Координирование деятельности по внедрению специального антикоррупционного образования // Современные проблемы науки и образования. - 2014. - №3. - С.268;

26. Николаев С.М. Специальное антикоррупционное образование в России: системный подход // Инновации в образовании. - 2014. - №6. - С.138-146.

27. Паньшин Д.Л. Некоторые аспекты антикоррупционного образования сотрудников подразделений Гоавтоинспекции России // Полицейская деятельность. - 2014. - №3. - С.286-292.

28. Прошина Е.М. К вопросу об антикоррупционном образовании государственных служащих // Участие структур гражданского общества в процессе предотвращения коррупции. Итоговая конференция по одноименной Программе / Под ред. М.Б. Горного. - СПб., 2000. - С. 97-101.

29. Сюзева Н.В. Об антикоррупционном образовании студентов организации СПО // В мире научных открытий. 2014. - №3.1 (51). - С.601-612.

30. Хайрутдинова Л.Р. Антикоррупционное просвещение как эффективный способ противодействия коррупции // Диалектика противодействия коррупции: материалы IV Всероссийской научно-практической конференции, 3 декабря 2014 г. - Казань, 2014. - С.188-191.

31. Хайрутдинова Л.Р. Антикоррупционное просвещение: понятие, цели и значение // Гуманитарные научные исследования. - 2015. - №1-1 (41). - С.106-109.

32. Чачников В.А. Антикоррупционное образование как наиболее эффективное и перспективное направление противодействия коррупции в органах внутренних дел // Полицейская деятельность. - 2014. - №6. - С.20-25.

33. Чашников В.А. Антикоррупционное образование в органах внутренних дел Российской Федерации (на примере Уральского юридического института Министерства внутренних дел Российской Федерации) // Право и образование. - 2015. - №3. - С.76-80.

34. Шедий М.В. Антикоррупционное образование кадров как фактор повышения эффективности государственной политики противодействия коррупции // Вестник государственного и муниципального управления. - 2014. №2-1 (12). - С.150-154.

35. Шедий М.В. Коррупция как социальное явление: социологический анализ: дис. ... д-ра социолог. наук. - М., 2014.

36. Юсупов М.Р. Антикоррупционное просвещение в России - апологет правовой грамотности // Вертикальная власть федерации. - 2015. - №2-3. - С.5.

37. Яковлев Е.А. Правовое регулирование и организация деятельности уголовно-исполнительной системы в сфере реализации антикоррупционного законодательства: дис. ... канд. юрид. наук. - Рязань, 2015.

38. О внесении изменений в отдельные постановления Правительства Калининградской области и признании утратившими силу отдельных постановлений Правительства Калининградской области: постановление Правительства Калининградской области от 19 сентября 2014 года №608 // Калининградская правда. - 2014. 2 октяб.

39. О департаменте региональной безопасности Костромской области: постановление Губернатора Костромской области от 14 мая 2009 года №104 (в ред. от 8.02.2012 №41) // Северная правда. - 2009. - 21 мая.

40. О министерстве юстиции Новосибирской области: постановление Губернатора Новосибирской области от 13июля 2012 года №120 (в ред. от 28.08.2014 №131) // Советская Сибирь. - 2012. - 31 июля. 
41. О противодействии коррупции в Белгородской области: закон Белгородской области от 7 мая 2010 года №338 // Белгородские известия. - 2010. - 28 мая;

42. О противодействии коррупции в Костромской области: закон Костромской области от 10 марта 2009 года №4504-3КО (ред. от 30.05.2013 №366-5-3КО) // СП-нормативные документы. - 2009. - 13 марта.

43. О противодействии коррупции в Республике Дагестан: Закон Республики Дагестан от 07.04.2009 №21 (в ред. от 12.03.2013 №12) //Собрание законодательства Республики Дагестан. - 2009. - №7. - Ст. 275.

44. Об организации и обеспечении работы «телефона доверия» для обращения граждан о злоупотреблениях коррупционной направленности с оказанием юридической консультативной помощи пострадавшим от коррупции: Постановление главы Николаевского муниципального района Волгоградской области от 14 июля 2010 года №1110 // Заволжье. - 2010. - 21 июля.

45. Об уполномоченном по правам человека в Ханты-Мансийском автономном округе - Югре: Закон Ханты-Мансийского автономного округа - Югры от 2 августа 1999 года №43-03 (в ред. от 31.03.2012 №35-03) // Собрание законодательство Ханты-Мансийского автономного округа. - 1999. - №7. - Ст.470.

46. Об утверждении положения о министерстве образования и науки Архангельской области: постановление Правительства Архангельской области от 27 марта 2014 года №120-пп (в ред. от 3.06.2014 №229-пп) // Волна. 2014. - 10 апр.

47. Об утверждении Положения об Управлении по вопросам реализации антикоррупционной политики КарачаевоЧеркесской Республики: указ Президента Карачаево-Черкесской Республики от 19 ноября 2010 года №237 // День Республики. - 2010. - 30 нояб.

48. Об утверждении программы «Антикоррупционное просвещение в Новосибирской области на 2015-2016 годы»: Постановление Правительства Новосибирской области от 28 января 2015 года №26-п // Советская Сибирь. 2015. - 21 февр.

49. Об утверждении Программы по антикоррупционному просвещению на 2014-2016 годы: распоряжение Правительства РФ от 14 мая 2014 года №816-р // Собрание законодательства РФ. - 2014. - №21. - Ст. 2721.

50. Кабанов П.А. Антикоррупционная агитация как информационное средство противодействия коррупции: понятие и содержание // Административное и муниципальное право.-2014.-№2.-С. 178-185. DOI: 10.7256/19992807.2014.2.10111.

51. Кабанов П.А. Антикоррупционная пропаганда как инструмент противодействия коррупции в республике Татарстан: вопросы повышения качества правового регулирования // Право и политика.-2013.-№9.-С. $1130-1138$. DOI: $10.7256 / 1811-9018.2013 .9 .9466$.

52. Кабанов П.А. Антикоррупционные функции подразделений кадровых служб по профилактике коррупционных и иных правонарушений органов публичной власти: понятие, содержание, вид // Административное и муниципальное право.-2014.-№9.-C. 981-992. DOI: 10.7256/1999-2807.2014.9.12769.

53. Кабанов П.А. Понятие и содержание антикоррупционной пропаганды как правовой категории в российском региональном антикоррупционном законодательстве // Административное и муниципальное право.-2013.-№ 9.C. 878-884. DOI: 10.7256/1999-2807.2013.9.9428.

54. Кабанов П.А. Полномочия специализированных региональных совещательных антикоррупционных органов в области информационного сопровождения формирования и реализации государственной политики противодействия коррупции: анализ правового регулирования и некоторые направления его совершенствования // Административное и муниципальное право.-2014.-№1.-C. 58-64. DOI: 10.7256/1999-2807.2014.1.10525.

55. Агеев В.Н. Правовые средства и механизмы противодействия коррупции // NB: Административное право и практика администрирования.-2012.-№1.-C. 112-134. URL: http://www.e-notabene.ru/al/article_410.html

\section{References (transliterated):}

1. Ageev V.N., Bikeev I.I., Kabanov P.A. i dr. Vse o korruptsii i protivodeistvii ei: terminologicheskii slovar' / pod obshch. red. I.I. Bikeeva, P.A. Kabanova: Seriya v 3 t. T.2. - Kazan': izd-vo «Poznanie», 2014.

2. Antikorruptsionnaya ekspertiza normativnykh pravovykh aktov i ikh proektov: terminologicheskii slovar' / avt.-sost. V.N. Ageev, I.I. Bikeev, P.A. Kabanov i dr.; ruk. avt. kollektiva P.A. Kabanov. - Kazan': Izd-vo «Poznanie», 2010.

3. Antikorruptsionnyi slovar'. - Bishkek: Ministerstvo ekonomiki Kyrgyzskoi Respubliki, 2013.

4. Akhmetova N.A., Guzenko V.N. Osnovy antikorruptsionnogo obrazovaniya v sovremennom uchebnom protsesse // Izvestiya Volgogradskogo gosudarstvennogo tekhnicheskogo universiteta. - 2013. - T.10. - №13. - S.16-18.

5. Bikeev I.I., Kabanov P.A. Antikorruptsionnoe obrazovanie kak odin iz instrumentov protivodeistviya korruptsii: voprosy ego formirovaniya i realizatsii v Respublike Tatarstan // Sledovatel'. - 2010. - №8. - №S.4-9.

6. Bikeev I.I., Kabanov P.A., Chirkov D.K. i dr. Korruptsiya i antikorruptsionnaya politika: terminologicheskii slovar' / pod obshch. red. G.I. Raikova, P.A. Kabanova, D.K. Chirkova. - 5-e izd., pererab. i dop. - M.: MediaPress, 2010.

7. Bikmukhametov A.E., Gazimzyanov R.R., Kabanov P.A., Raikov G.I. Chirkov D.K. i dr. Korruptsiya i antikorruptsionnaya politika: terminologicheskii slovar' / pod obshch. red. P.A. Kabanova. - M.: MediaPress, 2008.

8. Bikmukhametov A.E., Yusupov I.M. Dopolnitel'noe antikorruptsionnoe obrazovanie munitsipal'nykh sluzhashchikh: urovni i osnovnye napravleniya podgotovki // Aktual'nye problemy ekonomiki i prava. - 2010. - №4. - S.13-15. 
9. Gazimzyanov R.R., Kabanov P.A., Mulyukov Sh.M. Korruptsiya i bor'ba s nei: kratkii terminologicheskii slovar' / Pod obshch. red. R.F. Muratova, N.Kh. Safiullina. - Kazan', 2004.

10. Garmaev Yu.P., Falileev V.A. Realizatsiya mer antikorruptsionnogo prosveshcheniya organami prokuratury vo vzaimodeistvii s yuridicheskimi vuzami // Gosudarstvennaya vlast' i mestnoe samoupravlenie. - 2015. - №1. - S.11-15.

11. Glukhova A.A., Mytarev M.V., Shaposhnikov E.L. Analiticheskii obzor realizatsii obrazovatel'nykh programm v sfere protivodeistviya korruptsii v Nizhegorodskoi akademii MVD Rossii // Yuridicheskaya nauka i praktika: Vestnik Nizhegorodskoi akademii MVD Rossii. - 2014. - №2 (26). - S.174-179.

12. Emel'yanova N.I., Podkatilina M.L. Antikorruptsionnoe obrazovanie v rossiiskikh uchebnykh zavedeniyakh // Yuridicheskoe obrazovanie i nauka. - 2014. - №2. - S.15-18.

13. Zemlin A.I. O novatsiyakh i deformatsiyakh antikorruptsionnogo prosveshcheniya i vospitaniya v sovremennoi Rossii // Protivodeistvie terrorizmu. Problemy XXI veka. - COUNTER-TERRORISM. - 2014. - №2. - S.47-53.

14. Idrisova S.F. Problemy realizatsii kontseptsii nepreryvnogo antikorruptsionnogo obrazovaniya elity // Aktual'nye problemy ekonomiki i prava. - 2010. - №2. - S.156-160.

15. Kabanov P.A. Antikorruptsionnoe obrazovanie v organakh vnutrennikh del Rossiiskoi Federatsii: sovremennoe sostoyanie i perspektivy razvitiya // Sledovatel'. - 2011. - №2. - S.36-40.

16. Kabanov P.A. Antikorruptsionnoe obrazovanie kak pravovaya kategoriya regional'nogo antikorruptsionnogo zakonodatel'stva: opyt kriticheskogo analiza // Politseiskaya deyatel'nost'. - 2014. - №1. - S.81-92.

17. Kabanov P.A. Antikorruptsionnoe prosveshchenie kak sredstvo protivodeistviya korruptsii: ponyatie i soderzhanie // Aktual'nye problemy ekonomiki i prava. - 2014. - №4. - S.42-51.

18. Kabanov P.A. O formirovanii Programmy meropriyatii, napravlennykh na povyshenie urovnya pravosoznaniya grazhdan i populyarizatsiyu antikorruptsionnykh standartov povedeniya, osnovannykh na znanii obshchikh prav i obyazannostei // Sledovatel'. - 2014. - №1. - S.27-29.

19. Kabanov P.A. Ponyatie i soderzhanie antikorruptsionnogo prosveshcheniya kak sredstva profilaktiki korruptsii // Yuridicheskie issledovaniya. - 2015. - № 2. - S.12-27.

20. Kodan S.V. Antikorruptsionnaya podgotovka gosudarstvennykh sluzhashchikh i administrativnaya reforma // Chinovnik. - 2005. - №3(37). - S.12-18.

21. Koryakin V.M. Antikorruptsiya - 2014: prioritet - bor'be s «otkatami» i antikorruptsionnoe prosveshchenie voennosluzhashchikh // Pravo v Vooruzhennykh silakh. - 2014. - №12 (210). - S.8-13.

22. Kos D. Opyt evropeiskikh stran v sfere sozdaniya i funktsionirovaniya spetsial'nogo organa, otvetstvennogo za koordinatsiyu gosudarstvennykh mer po protivodeistviyu i predotvrashcheniyu korruptsii // Rossiya - Evropa. Vmeste protiv korruptsii: Materialy sovmestnogo proekta «Razrabotka zakonodatel'nykh i inykh mer preduprezhdeniya korruptsii v Rossiiskoi Federatsii» (RUCOLA-2). - M., 2008. - Chast' 2. - S.180-181.

23. Nikolaev S.M. Vvedenie v problemu spetsial'nogo antikorruptsionnogo obrazovaniya // Fundamental'nye issledovaniya. - 2014. - №9-1. - S.185-189.

24. Nikolaev S.M. Znaniya, umeniya, navyki i kompetentsii pri realizatsii antikorruptsionnogo obrazovaniya // Vestnik gumanitarnogo nauchnogo obrazovaniya. - 2013. - №8 (34). - S.7-9.

25. Nikolaev S.M. Koordinirovanie deyatel'nosti po vnedreniyu spetsial'nogo antikorruptsionnogo obrazovaniya // Sovremennye problemy nauki i obrazovaniya. - 2014. - №3. - S.268;

26. Nikolaev S.M. Spetsial'noe antikorruptsionnoe obrazovanie v Rossii: sistemnyi podkhod // Innovatsii v obrazovanii. 2014. - №6. - S.138-146.

27. Pan'shin D.L. Nekotorye aspekty antikorruptsionnogo obrazovaniya sotrudnikov podrazdelenii Goavtoinspektsii Rossii // Politseiskaya deyatel'nost'. - 2014. - №3. - S.286-292.

28. Proshina E.M. K voprosu ob antikorruptsionnom obrazovanii gosudarstvennykh sluzhashchikh // Uchastie struktur grazhdanskogo obshchestva $\mathrm{v}$ protsesse predotvrashcheniya korruptsii. Itogovaya konferentsiya po odnoimennoi Programme / Pod red. M.B. Gornogo. - SPb., 2000. - S. 97-101.

29. Syuzeva N.V. Ob antikorruptsionnom obrazovanii studentov organizatsii SPO // V mire nauchnykh otkrytii. - 2014. №3.1 (51). - S.601-612.

30. Khairutdinova L.R. Antikorruptsionnoe prosveshchenie kak effektivnyi sposob protivodeistviya korruptsii // Dialektika protivodeistviya korruptsii: materialy IV Vserossiiskoi nauchno-prakticheskoi konferentsii, 3 dekabrya 2014 g. - Kazan', 2014. - S.188-191.

31. Khairutdinova L.R. Antikorruptsionnoe prosveshchenie: ponyatie, tseli i znachenie // Gumanitarnye nauchnye issledovaniya. - 2015. - №1-1 (41). - S.106-109.

32. Chachnikov V.A. Antikorruptsionnoe obrazovanie kak naibolee effektivnoe i perspektivnoe napravlenie protivodeistviya korruptsii v organakh vnutrennikh del // Politseiskaya deyatel'nost'. - 2014. - №6. - S.20-25.

33. Chashnikov V.A. Antikorruptsionnoe obrazovanie v organakh vnutrennikh del Rossiiskoi Federatsii (na primere Ural'skogo yuridicheskogo instituta Ministerstva vnutrennikh del Rossiiskoi Federatsii) // Pravo i obrazovanie. - 2015. - №3. S.76-80.

34. Shedii M.V. Antikorruptsionnoe obrazovanie kadrov kak faktor povysheniya effektivnosti gosudarstvennoi politiki protivodeistviya korruptsii // Vestnik gosudarstvennogo i munitsipal'nogo upravleniya. - 2014. - №2-1 (12). S.150-154. 
35. Shedii M.V. Korruptsiya kak sotsial'noe yavlenie: sotsiologicheskii analiz: dis. ... d-ra sotsiolog. nauk. - M., 2014.

36. Yusupov M.R. Antikorruptsionnoe prosveshchenie v Rossii - apologet pravovoi gramotnosti // Vertikal'naya vlast' federatsii. - 2015. - №2-3. - S.5.

37. Yakovlev E.A. Pravovoe regulirovanie i organizatsiya deyatel'nosti ugolovno-ispolnitel'noi sistemy v sfere realizatsii antikorruptsionnogo zakonodatel'stva: dis. ... kand. yurid. nauk. - Ryazan', 2015.

38. O vnesenii izmenenii v otdel'nye postanovleniya Pravitel'stva Kaliningradskoi oblasti i priznanii utrativshimi silu otdel'nykh postanovlenii Pravitel'stva Kaliningradskoi oblasti: postanovlenie Pravitel'stva Kaliningradskoi oblasti ot 19 sentyabrya 2014 goda №608 // Kaliningradskaya pravda. - 2014. - 2 oktyab.

39. O departamente regional'noi bezopasnosti Kostromskoi oblasti: postanovlenie Gubernatora Kostromskoi oblasti ot 14 maya 2009 goda №104 (v red. ot 8.02.2012 №41) // Severnaya pravda. - 2009. - 21 maya.

40. O ministerstve yustitsii Novosibirskoi oblasti: postanovlenie Gubernatora Novosibirskoi oblasti ot 13 iyulya 2012 goda №120 (v red. ot 28.08.2014 №131) // Sovetskaya Sibir'. - 2012. - 31 iyulya.

41. O protivodeistvii korruptsii v Belgorodskoi oblasti: zakon Belgorodskoi oblasti ot 7 maya 2010 goda №338 // Belgorodskie izvestiya. - 2010. - 28 maya;

42. O protivodeistvii korruptsii v Kostromskoi oblasti: zakon Kostromskoi oblasti ot 10 marta 2009 goda №450-4-ZKO (red. ot 30.05.2013 №366-5-ZK0) // SP-normativnye dokumenty. - 2009. - 13 marta.

43. O protivodeistvii korruptsii v Respublike Dagestan: Zakon Respubliki Dagestan ot 07.04.2009 №21 (v red. ot 12.03 .2013 №12) //Sobranie zakonodatel'stva Respubliki Dagestan. - 2009. - №7. - St. 275.

44. Ob organizatsii i obespechenii raboty «telefona doveriya» dlya obrashcheniya grazhdan o zloupotrebleniyakh korruptsionnoi napravlennosti s okazaniem yuridicheskoi konsul'tativnoi pomoshchi postradavshim ot korruptsii: Postanovlenie glavy Nikolaevskogo munitsipal'nogo raiona Volgogradskoi oblasti ot 14 iyulya 2010 goda №1110 // Zavolzh'e. - 2010. - 21 iyulya.

45. Ob upolnomochennom po pravam cheloveka v Khanty-Mansiiskom avtonomnom okruge - Yugre: Zakon KhantyMansiiskogo avtonomnogo okruga - Yugry ot 2 avgusta 1999 goda №43-OZ (v red. ot 31.03.2012 №35-OZ) // Sobranie zakonodatel'stvo Khanty-Mansiiskogo avtonomnogo okruga. - 1999. - №7. - St.470.

46. Ob utverzhdenii polozheniya o ministerstve obrazovaniya i nauki Arkhangel'skoi oblasti: postanovlenie Pravitel'stva Arkhangel'skoi oblasti ot 27 marta 2014 goda №120-pp (v red. ot 3.06.2014 №229-pp) // Volna. - 2014 . - 10 apr.

47. Ob utverzhdenii Polozheniya ob Upravlenii po voprosam realizatsii antikorruptsionnoi politiki Karachaevo-Cherkesskoi Respubliki: ukaz Prezidenta Karachaevo-Cherkesskoi Respubliki ot 19 noyabrya 2010 goda №237 // Den' Respubliki. 2010. - 30 noyab.

48. Ob utverzhdenii programmy «Antikorruptsionnoe prosveshchenie v Novosibirskoi oblasti na 2015-2016 gody»: Postanovlenie Pravitel'stva Novosibirskoi oblasti ot 28 yanvarya 2015 goda №26-p // Sovetskaya Sibir'. - 2015. - 21 fevr.

49. Ob utverzhdenii Programmy po antikorruptsionnomu prosveshcheniyu na 2014-2016 gody: rasporyazhenie Pravitel'stva RF ot 14 maya 2014 goda №816-r // Sobranie zakonodatel'stva RF. - 2014. - №21. - St. 2721.

50. Kabanov P.A. Antikorruptsionnaya agitatsiya kak informatsionnoe sredstvo protivodeistviya korruptsii: ponyatie i soderzhanie // Administrativnoe i munitsipal'noe pravo.-2014.-№2.-C. 178-185. DOI: 10.7256/1999-2807.2014.2.10111.

51. Kabanov P.A. Antikorruptsionnaya propaganda kak instrument protivodeistviya korruptsii v respublike Tatarstan: voprosy povysheniya kachestva pravovogo regulirovaniya // Pravo i politika.-2013.-№9.-C. 1130-1138. DOI: 10.7256/18119018.2013.9.9466.

52. Kabanov P.A. Antikorruptsionnye funktsii podrazdelenii kadrovykh sluzhb po profilaktike korruptsionnykh i inykh pravonarushenii organov publichnoi vlasti: ponyatie, soderzhanie, vid // Administrativnoe i munitsipal'noe pravo.2014.-№9.-C. 981-992. DOI: 10.7256/1999-2807.2014.9.12769.

53. Kabanov P.A. Ponyatie i soderzhanie antikorruptsionnoi propagandy kak pravovoi kategorii v rossiiskom regional'nom antikorruptsionnom zakonodatel'stve // Administrativnoe i munitsipal'noe pravo.-2013.-№ 9.-C. 878-884. DOI: 10.7256/1999-2807.2013.9.9428.

54. Kabanov P.A. Polnomochiya spetsializirovannykh regional'nykh soveshchatel'nykh antikorruptsionnykh organov v oblasti informatsionnogo soprovozhdeniya formirovaniya i realizatsii gosudarstvennoi politiki protivodeistviya korruptsii: analiz pravovogo regulirovaniya i nekotorye napravleniya ego sovershenstvovaniya // Administrativnoe i munitsipal'noe pravo.-2014.-№1.-C. 58-64. DOI: 10.7256/1999-2807.2014.1.10525.

55. Ageev V.N. Pravovye sredstva i mekhanizmy protivodeistviya korruptsii // NB: Administrativnoe pravo i praktika administrirovaniya.-2012.-№1.-C. 112-134. URL: http://www.e-notabene.ru/al/article_410.html 